6. Cown St, Steel KJ. Manual for the identification of medical bacteria, $2^{\text {nd }}$ ed. Cambridge, Cambridge University Press, 1974, p 73.

7. Baur AW, Kirby WMM, Sherris JC, Turck M. Antibiotic susceptibility testing by standard single disk method. Am J Clin Pathol. 1966; 45: 493-96.

8. Albertini MT, Benoit C, Berardi L, Berrounane Y, Boisivon A, Cahen P. Surveillance of methicillinresistant Staphylococcus aureus (MRSA) and Enterobacteriaceae producing extended-spectrum beta-lactamase (ESBLE) in Northern France: A fiveyear multicenter incidence study. J Hosp Infect. 2002; 52: 107-13

9. Panlilio AL, Culver DH, Gaynes RP, Banerjee S, Henderson TS, Tolson JS, et al. Methicillin resistant Staphylococcus aureus in U.S. hospitals, 1975-1991. Infect Control Hosp Epidemiol. 1992; 13: 582-86.

10. Mehta AP, Rodrigues C, Seth K, Jani S, Hakimiyan A, Fazalbhoy N. Control of methicillin resistant Staphylococcus aureus in a tertiary care center- A five-year study. J Med Microbiol. 1998; 16: 31-34.

11. Zaman R, Dibb WL. Methicillin resistant Staphylococcus aureus (MRSA) isolated in Saudi Arabia: Epidemiology and antimicrobial resistance pattern. J Hosp Infect. 1994; 26: 297-300.

12. Asghar AH, Momenah AM. Methicillin resistance among Staphylococcus aureus isolates from Saudi Hospitals. Med Princ Pract. 2006; 15: 52-55.

\section{Prevalence of hepatitis $C$ virus infection in rural adult population of Bangladesh}

Hepatitis $\mathrm{C}$ virus (HCV) infection is an important global health problem and may cause acute and chronic infection in man and is one of the most common causes of chronic liver disease, cirrhosis of liver and hepatocellular carcinoma. HCV accounts for $40 \%$ of chronic liver disease ${ }^{1}$. It is estimated that about $3 \%$ of global population is infected with $\mathrm{HCV}$ although prevalence ranges from 0.1 to more than $12 \%$, depending on country which equals to approximately 170 million chronic carriers worldwide ${ }^{2}$. In United States, the overall $\mathrm{HCV}$ prevalence rate is $1.8 \%$, with a relatively high prevalence among African Americans (3.2\%) and Hispanic $(2.1 \%)$ than the non-Hispanic white $(1.5 \%)^{3}$

A study among truck driver and helper in Bangladesh showed the prevalence of $\mathrm{HCV}$ infection was $<1 \%{ }^{4}$. In another study the prevalence of $\mathrm{HCV}$ infection was higher among intravenous drug abusers $(24.8 \%)$ in comparison to non-drug abusers $(5.8 \%)^{5}$.

Khan et $\mathrm{al}^{6}$ showed that $2.4 \%$ of Bangladeshi professional blood donors were anti-HCV positive whereas it was $0.6 \%$ of Japanese voluntary blood donors.
We conducted a cross-sectional population based study over the population living village of Kaligonj Upazilla under the District Gazipur, Bangladesh during the period from July 2005 to June 2006 .

Inclusion criteria were apparently healthy adult voluntarily participants aged $\geq 18$ years and both male and female were included on the basis of availability.

Exclusion criteria were age less than 18 years irrespective of sex, subject unwilling to participate and history of jaundice within last 6 months.

Socio-demographic data such as age, sex, marital status, occupation, education, yearly income and smoking habit were recorded. Risk factors for $\mathrm{HCV}$ infection were analyzed using a questionnaire including previous history of childhood immunization by old method using unsterilized and /or re-used needle, history of needle prick, major operation, dearntal procedure, shaving pattern, jaundice of parents- brothers, sisters, method of circumcision and history of intravenous drug abuse.

Data were collected using a predesigned, field tested structured questionnaire. All variable were noted in data collection sheet. Data sheet of population studied was filled-up after face to face interview. Prior to interview a public motivation program was conducted for ensuring community participation. During counseling special emphasis was given to clinical outcome of $\mathrm{HCV}$ infection. Risk, discomfort, confidentiality, privacy about collection of blood and data in the ethical point of view were discussed with the participants. Objectives of study discussed thoroughly. After recording of data $5 \mathrm{ml}$ of blood from each individual were collected aseptically using disposal syringe and serum was separated by centrifuge machine and transported to Dhaka where serum was stored in deep frieze at $-20^{\circ} \mathrm{C}$. Then the sera were tested for anti-HCV by a commercial kit according to standard operating procedure of manufactures instruction (Biotec $\mathrm{HCV}$ rapid device, UK). Sensitivity was $96.8 \%$ and specificity was $99 \%$. All anti-HCV positive cases were confirmed by ELISA method.

Out of 501 adults, 218 subjects were male and 282 were female. Mean age of subject was $35 \pm 14.82$ years. Most of subjects were less than 40 years of age (69.4\%) (Table I and II). Educational status of study population showed most of the subjects was educated (72\%). Most of the subjects (85.4\%) had completed EPI coverage. Only 73 (14.6\%) subjects were found uncovered by EPI program. Out of 283 females, 194 female subjects were completed their TT vaccination. Overall TT coverage was $68.55 \%$ (Table II). Study showed that 279 (55.7\%) subjects 
had history of reused needle, 73 (14.6\%) subjects had history of disposable needle use. In this study $58(11.6 \%)$ subjects had history of more than two time needle pricking and $56(11.2 \%)$ subjects had history of one time needle pricking in last one year (Table III). Three subjects were found to be antiHCV positive $(0.6 \%)$ of which two subjects were male. One subject was below 40 years and two subjects were above sixty years of age. Two persons were educated. Among seropositive subject, 2 were farmer and one was housewife. Two subjects had history of barber shaving. One subject had history of more than two times needle pricking in last one year. Two subjects had history of reused needle in life, blood transfusion, drug abuse or jaundice were not present any subject. Multiple regression analysis could not identify any associated risk factor.

Table I: Demographic data

\begin{tabular}{|c|c|c|}
\hline Variable & & $\mathrm{n} /(\%)$ \\
\hline \multirow[t]{3}{*}{ Population size } & Sex & \\
\hline & Male & $218(43.5)$ \\
\hline & Female & $282(56.5)$ \\
\hline \multicolumn{3}{|l|}{ Occupation } \\
\hline & House wife & $250(49.9)$ \\
\hline & Farmer & $114(22.8)$ \\
\hline & Student & $53(10.6)$ \\
\hline & Service holder & $46(9.2)$ \\
\hline & Businessman & $22(4.4)$ \\
\hline & Day lab our & $2(0.4)$ \\
\hline \multicolumn{3}{|l|}{ Education } \\
\hline & Illiterate & $142(28.3)$ \\
\hline & Primary & $53(10.6)$ \\
\hline & Secondary & $100(20)$ \\
\hline & Higher Secondary & $31(6.2)$ \\
\hline & Graduate & $23(4.6)$ \\
\hline & Post-graduate & $16(3.2)$ \\
\hline
\end{tabular}

Table II: Immunization pattern of study population

\begin{tabular}{lcr}
\hline Variable & $\begin{array}{c}\text { Response to } \\
\text { question }\end{array}$ & $\mathrm{n}(\%)$ \\
\hline EPI coverage & Yes & $482(85.4)$ \\
& No & $73(14.6)$ \\
TT coverage by female subjects & Total & $501(100)$ \\
& Yes & $194(38.7)$ \\
& No & $44(8.8)$ \\
& N/A & $263(52.4)$ \\
& Total & $501(100)$ \\
\hline
\end{tabular}

Table III: Frequency of needle pricking in last one year by study population

\begin{tabular}{lr}
\hline Pattern of needle prick & $\mathrm{n}(\%)$ \\
\hline Two or more times & $58(11.6)$ \\
One time & $56(11.2)$ \\
Never used & $387(77.2)$ \\
\hline Total & $501(100)$ \\
\hline
\end{tabular}

There is no documented data on seroprevalence of $\mathrm{HCV}$ infection in rural adult population of Bangladesh. In this study we found anti $\mathrm{HCV}$ positive in $0.6 \%$ cases. This prevalence rate is consistent with that found in study done by Laura Gibney ${ }^{4}$, Khan et $\mathrm{al}^{6}$ and Kuperan $\mathrm{P}$ et. al ${ }^{7}$. but lower than that of reported in Australia ${ }^{8}, \operatorname{Japan}^{9}$, Malaysia $^{10}$, Pakistan $^{11}$ and India ${ }^{12}$. Lower prevalence of anti-HCV in this study mighty be due to several factors. Firstly, rural people are less exposed to blood transfusion, needle prick, parental drug addiction and extramarital sexual activities. Secondly, negative anti-HCV does not exclude possibility of having HCV infection. Thirdly, the difference in socio-demographic background of rural population may be a contributing factor. On conclusion, this study shows that prevalence of $\mathrm{HCV}$ infection in rural adult population of Bangladesh is $0.6 \%$ which is relatively lower than that of developed countries.

Authors are grateful to Dr. Habib Sadat Choudhury, Moulana Bhasani Medical College, Dhaka for help in statistical analysis and procedure. All authors are also grateful to Roche Bangladesh Ltd for supplying anti-HCV kits. We are indebted to participants from village Jangalia, Upazilla Kaligong, District Gazipur, Bangladesh.

A.B.M. Safiullah, Md. Muzibur Rahman Bhuiyan, M.A. Rahim Miah and A.S.M.A. Raihan

Department of Gastroenterology, Bangabandhu Sheikh Mujib Medical University, Shahbag, Dhaka, Bangladesh. e-mail: safigastro@yahoo.com

DOI: $10.3329 /$ bmrcb.v35i1.2319

\section{References}

1. Center for Disease Control. Recommendation for prevention and control of $\mathrm{HCV}$ infection and $\mathrm{HCV}$ related disease. MMWR Marly Morty Weekly Report 1998; 47: 1-40.

2. Global surveillance and control of hepatitis C. Reports of a WHO Consultation organized in collaboration with the Viral Hepatitis Prevention Board, Antwerp, Belgium. J Viral Hepatol. 1999; 6: 35-47.

3. Alter MJ, Kruszon- Morand D, Nainan OV, McQuillan GM, Gao F, Mayor LA. Prevalence of hepatitis C virus in United States, 1988 through 1994. N Engl J Med. 1999; 341: 556-62. 
4. Gibney L, Saquib N, Metzger J, Chowdhury P, Siddiqui MA, Hassan MS. Human immunodeficiency virus, hepatitis B, C and D in Bangladesh's trucking industry: Prevalence and risk factors. Int J Epidemiol. 2001; 30: 878-84.

5. Shirin $\mathrm{T}$, Ahmed $\mathrm{T}$, Iqbal A, Islam $\mathrm{M}$, Islam $\mathrm{MN}$. Prevalence and risk factors of hepatitis B virus, hepatitis $\mathrm{C}$ virus and Human Immunodeficiency Virus infection among drug addicts in Bangladesh. J Health Population Nutr. 2000; 18: 145-50.

6. Khan M, Hussain M, Yano M, Hashizume K, Yousuf M, Tanaka E, Masumoto A, Furuta S. Comparison of seroepidemiology of hepatitis $\mathrm{C}$ in blood donors between Bangladesh and Japan. Gastroenterol Jpn. 1993; 28 (Suppl 5): 28-31.

7. Kuperan P, Choon AT, Ding SH, Lee G. Prevalence of antibodies to hepatitis $\mathrm{C}$ virus in relation to surrogate markers in a blood donor population in Singapore. Southeast Asian J Trop Med Pub Health 1993; 24(Suppl 1): 127-29.

8. Amin J, Gidding H, Gibert G, Backhouse J, Kaldor J, Dore G, Burgess $\mathrm{M}$, Hepatitis $\mathrm{C}$ prevalence: A nationwide serosurvey. Commun Dis Intell. 2004; 28: 517-21.

9. Tanaka J, Kumagai J, Katayama K, Komiya Y, Mizui M, Yamanaka R, Suzuki K, Miyakawa Y, YoshizawaH. Sex and age specific carriers of hepatitis $\mathrm{B}$ and $\mathrm{C}$ viruses in Japan estimated by the prevalence in the 3,485,748 first-time blood donors during 19952000. Intervirology 2004; 47: 32-40.

10. Duraisamy G, Zuridah H, Ariffin MY. Prevalence of hepatitis $\mathrm{C}$ virus antibodies in blood donors in Malaysia. Med J Mal. 1993; 48: 313-16.

11. Aktar S, Younus M, Adil S, Jafri SH, Hassan F. Hepatitis C Virus infection in a symptomatic male volunteer blood donors in Karachi, Pakistan. J Viral Hepatol. 2004; 11: 527-35.

12. Panigrahi AK, Panda SK, Dixit RK, Rao KV, Acharya SK, Dasarathy S, Nanu A. Magnitude of hepatitis C virus infection in India: Prevalence in healthy blood donors, acute and chronic liver disease. J Med Virol. 1997; 51: 167-74. 